\title{
Nitsche法を用いた シェル要素とソリッド要素の接合
}

\author{
山本 剛大 ${ }^{1} \cdot$ 山田 貴博 ${ }^{2} \cdot$ 松井 和己 $^{3}$ \\ ${ }^{1}$ 博（工） 東北大学助教大学院工学研究科（９ 980-8579 仙台市青葉区荒巻字青葉 6-6-06） \\ E-mail: takeki.yamamoto.c2@tohoku.ac.jp \\ 2学博 横浜国立大学教授大学院環境情報研究院（干 240-8501 横浜市保土ケ谷区常盤台 79-7） \\ 3 博（工） 横浜国立大学准教授 大学院環境情報研究院（干 240-8501 横浜市保土ヶ谷区常盤台 79-7）
}

\begin{abstract}
複雑な 3 次元構造物に対する有限要素解析において, シェル要素とソリッド要素を適切に接続することによ り，低コストで高精度な数值計算を実現する手法について検討する．異種要素を接続する手法として提案され ている多点拘束法や Penalty 法による手法では, 接続境界において変位の連続性のみが考慮されており, 接続境 界近傍でのソリッド要素に不自然な変形状態が生じる. 本研究では, 接続境界での応力ベクトルの連続性を考 慮できる Nitsche 法を適用することで, シェル要素とソリッド要素を適切に接続する手法を提案する. 本手法で は，シェル要素とソリッド要素で評価される応力分布から接続境界の応力状態を表現することで, 接続境界近 傍において自然な変形および応力分布を示すモデル化が実現できる.
\end{abstract}

Key Words: shell element, solid element, combined modeling, Nitsche's method

\section{1. はじめに}

有限要素法を用いた構造解析において, 局所的な力 学挙動の評価には連続体要素の使用が推奖される.し かしながら, 解析対象の形状を考慮せずに解析対象全 体を 1 種類の要素で離散化する手法では, 精度の高い 数值解を得るためにメッシュ解像度の改良や計算コス トの増加が避けられない，たとえば，橋梁などの構造 の大部分がシェル構造やはり構造とみなせる解析対象 に連続体要素を適用すると, 計算コストが膨大となる. それを解決するために, 解析対象全体を連続体要素で モデル化するのではなく, 部分的に構造要素と連続体 要素を使い分ける技術として, 構造要素と連続体要素 を接続したモデル化手法の開発が望まれている.

解析対象のモデル化において, 構造要素と連続体要 素の接続を想定する. 節点自由度の異なる要素を接続 する手法として, 変位の従属関係を定義する多点拘束 (Multiple Point Constraint, MPC) 法 ${ }^{1), 2}$ や同様の拘束条 件をPenalty 法 ${ }^{3)}$ によって課す手法が提案されている。こ れらの手法では, 並進変位のみを自由度に持つソリッド 要素と並進変位と回転角を自由度とするはり要素, シェ ル要素に対して，節点の接続条件が検討されてきた，そ のため, 応力状態やひずみ状態が複雑となる構造物を 対象とする数值計算では, 接続部分を含めて計算結果 に対する信頼性が低下寸る，さらに，変形に対する連 続性のみが考慮される場合, 構造要素の変形状態に対 する制約から，接続境界近傍でのソリッド要素に不自
然な変形状態が生じる. それに対して，接続される 2 種 類の要素間の特性を結びつける特殊な接合要素4) や接 合部分の界面において応力仕事のつりあい方程式を離 散化する手法 ${ }^{5)}$ は，接続部分の変位に対する連続性を 課す MPC 法に加えて, 応力状態の連続性を課す手法と して提案されている.

近年, 連続体要素において分割された領域の解を接 続する手法(6),7) が注目されている.メッシュが整合し ない 2 領域間の解の接続手法7) や重複するメッシュの 界面における解の接続 ${ }^{8)}$ において, Nitsche 法" ${ }^{9}$ が適用 されている. Nitsche 法は内部 Penalty 不連続 Galerkin 法 (Interior Penalty Discontinuous Galerkin Method, IPDGM） 10) の背景にも用いられる手法であり, 連続体の モデル化に加えて, 不連続体のモデル化 ${ }^{11)}$ や 2 物体の 接触問題12) への有用性が示されている. また, Nitsche 法による解の接続では変位ベクトルに加えて, 応力心゙ クトルの連続性が考慮されるため, 構造要素の変形状 態に対する制約から生じるソリッド要素の不自然な変 形を改善することが可能となる。はり要素とソリッド 要素の接続に Nitsche 法を適用した手法13) では, はり 理論から計算できる応力分布をソリッド要素でモデル 化された領域の接続境界における応力ベクトルとして いる. そこで本研究では, 連続体における分割された 領域の解を接続する考え方を用いることにより，接続 境界で 3 次元の応力ベクトルの連続性を考慮し, シェ ル要素とソリッド要素を接続する手法を開発する. 本 論文は, Nitsche 法に基づくシェル要素とソリッド要素 


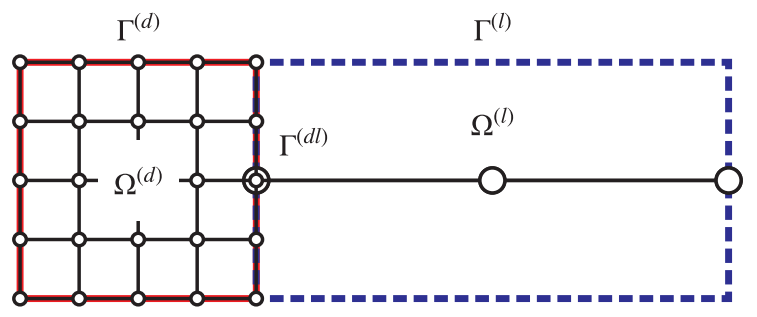

Domain of solid

Domain of shell

図-1 領域分割

の接続手法を提案し, 数值計算例においてその有用性 を示すものである.

\section{2. 領域分割に基づく定式化}

\section{(1) 問題設定}

本研究では, 図-1に示すような全体領域 $\Omega$ をソリッ ド要素によってモデル化されるソリッド領域 $\Omega^{(d)}$ とシェ ル要素によってモデル化されるシェル領域 $\Omega^{(l)}$ に分割し, それぞれの領域における変位を接続する.ソリッド領域 $\Omega^{(d)}$ の境界を $\Gamma^{(d)}$, シェル領域 $\Omega^{(l)}$ の境界を $\Gamma^{(l)}$ とし, $\Gamma^{(d)}$ と $\Gamma^{(l)}$ の共通部分である領域間境界を $\Gamma^{(d l)}=\Gamma^{(d)} \cap \Gamma^{(l)}$ とする.

ソリッド領域 $\Omega^{(d)}$ において定義される変位場 $\mathbf{u}^{(d)}$, シェ ル領域 $\Omega^{(l)}$ において定義される変位場 $\mathbf{u}^{(l)}$ に対して, 次 のような境界值問題を考える.

$$
\begin{aligned}
\boldsymbol{\nabla} \cdot \boldsymbol{\sigma}^{(d)}\left(\mathbf{u}^{(d)}\right)+\mathbf{b}^{(d)} & =\mathbf{0} & & \text { in } \Omega^{(d)} \\
\boldsymbol{\nabla} \cdot \boldsymbol{\sigma}^{(l)}\left(\mathbf{u}^{(l)}\right)+\mathbf{b}^{(l)} & =\mathbf{0} & & \text { in } \Omega^{(l)} \\
\mathbf{u}^{(d)} & =\overline{\mathbf{u}}^{(d)} & & \text { on } \Gamma_{u}^{(d)} \\
\mathbf{u}^{(l)} & =\overline{\mathbf{u}}^{(l)} & & \text { on } \Gamma_{u}^{(l)} \\
\boldsymbol{\sigma}^{(d)}\left(\mathbf{u}^{(d)}\right) \mathbf{n}^{(d)} & =\overline{\mathbf{t}}^{(d)} & & \text { on } \Gamma_{t}^{(d)} \\
\boldsymbol{\sigma}^{(l)}\left(\mathbf{u}^{(l)}\right) \mathbf{n}^{(l)} & =\overline{\mathbf{t}}^{(l)} & & \text { on } \Gamma_{t}^{(l)}
\end{aligned}
$$

ここで, $\boldsymbol{\sigma}^{(d)}\left(\mathbf{u}^{(d)}\right)$ はソリッド領域 $\Omega^{(d)}$ における変位 場 $\mathbf{u}^{(d)}$ から算出される Cauchy 応力テンソル, $\sigma^{(l)}\left(\mathbf{u}^{(l)}\right)$ はシェル領域 $\Omega^{(l)}$ における変位場 $\mathbf{u}^{(l)}$ から算出される Cauchy 応力テンソル, $\mathbf{b}^{(d)}, \mathbf{b}^{(l)}$ は物体力ベクトル, $\mathbf{t}^{(d)}$, $\mathbf{t}^{(l)}$ は表面力ベクトルである。また， $\mathbf{n}^{(d)}$ はソリッド領 域の境界 $\Gamma^{(d)}$ に対する外向き単位法線ベクトル, $\mathbf{n}^{(l)}$ は シェル領域の境界 $\Gamma^{(l)}$ に対する外向き単位法線ベクトル とする。領域間境界 $\Gamma^{(d l)}$ 上では,

$$
\mathbf{n}^{(d)}=-\mathbf{n}^{(l)}=\mathbf{n}
$$

の関係が成り立つ. 境界については， $\Gamma_{u}^{(d)}, \Gamma_{u}^{(l)}$ が変位 場 $\mathbf{u}$ に対して幾何学的境界条件が課される境界, $\Gamma_{t}^{(d)}$, $\Gamma_{t}^{(l)}$ が表面力 $\mathbf{t}$ に対して力学的境界条件が課される境界
を意味する.これらの境界に対して，

$$
\begin{aligned}
\Gamma_{u}^{(d)} \cup \Gamma_{t}^{(d)} \cup \Gamma^{(d l)} & =\Gamma^{(d)} \\
\Gamma_{u}^{(d)} \cap \Gamma_{t}^{(d)} & =\emptyset \\
\Gamma_{u}^{(d)} \cap \Gamma^{(d l)} & =\emptyset \\
\Gamma_{t}^{(d)} \cap \Gamma^{(d l)} & =\emptyset \\
\Gamma_{u}^{(l)} \cup \Gamma_{t}^{(l)} \cup \Gamma^{(d l)} & =\Gamma^{(l)} \\
\Gamma_{u}^{(l)} \cap \Gamma_{t}^{(l)} & =\emptyset \\
\Gamma_{u}^{(l)} \cap \Gamma^{(d l)} & =\emptyset \\
\Gamma_{t}^{(l)} \cap \Gamma^{(d l)} & =\emptyset
\end{aligned}
$$

を仮定する。

領域間の解に対する接続条件は，変位ベクトルおよ び応力ベクトルの連続性として,

$$
\begin{aligned}
\mathbf{u}^{(d)} & =\mathbf{u}^{(l)} & & \text { on } \Gamma^{(d l)} \\
\boldsymbol{\sigma}^{(d)} \mathbf{n} & =\boldsymbol{\sigma}^{(l)} \mathbf{n} & & \text { on } \Gamma^{(d l)}
\end{aligned}
$$

と表現される.

\section{(2) 変分法的定式化}

本研究では弾性体の大変形問題を想定し, 材料構成 則が超弾性体として記述されるものとする。このとき, 式 (1) から式 (6) のソリッド領域 $\Omega^{(d)}$ とシェル領域 $\Omega^{(l)}$ において定義される変位場 $\mathbf{u}^{(d)}, \mathbf{u}^{(l)}$ に対する境界值問 題は，全ポテンシャルエネルギー汎関数 Пの最小化問 題として,

$$
\begin{aligned}
\Pi\left(\mathbf{u}^{(d)}, \mathbf{u}^{(l)}\right)= & \int_{{ }^{0} \Omega^{(d)}} W^{(d)}\left(\mathbf{F}^{(d)}\right) \mathrm{d} \Omega \\
& -\int_{{ }^{\Omega^{(d)}}} \mathbf{u}^{(d)} \cdot \mathbf{b}^{(d)} \mathrm{d} \Omega-\int_{{ }^{T^{(d)}}} \mathbf{u}^{(d)} \cdot \overline{\mathbf{t}}^{(d)} \mathrm{d} \Gamma \\
& +\int_{{ }^{0} \Omega^{(l)}} W^{(l)}\left(\mathbf{F}^{(l)}\right) \mathrm{d} \Omega \\
& -\int_{{ }^{t} \Omega^{(l)}} \mathbf{u}^{(l)} \cdot \mathbf{b}^{(l)} \mathrm{d} \Omega-\int_{{ }^{t} \Gamma^{(l)}} \mathbf{u}^{(l)} \cdot \overline{\mathbf{t}}^{(l)} \mathrm{d} \Gamma
\end{aligned}
$$

と定義できる。ここで， $\mathbf{F}^{(d)}$ はソリッド領域の変位場 $\mathbf{u}^{(d)}$ から算出される変形勾配テンソル， $\mathbf{F}^{(l)}$ はシェル領 域の変位場 $\mathbf{u}^{(l)}$ から算出される変形勾配テンソルであ り, $W^{(d)}\left(\mathbf{F}^{(d)}\right)$ はソリッド領域でのひずみエネルギー密 度関数, $W^{(l)}\left(\mathbf{F}^{(l)}\right)$ はシェル領域でのひずみエネルギー 密度関数である.

汎関数 (18) の最小化問題に対する付帯条件は, 変位 場 $\mathbf{u}^{(d)}, \mathbf{u}^{(l)}$ に対する幾何学的境界条件 (3), (4) と領域 間境界 $\Gamma^{(d l)}$ における変位場の接続条件 $(16)$ となる。

\section{(3) 変位場に対する接続条件}

ソリッド領域を六面体 1 次要素で離散化すると, 変 位場 $\mathbf{u}^{(d)}$ は節点の変位ベクトル $\overline{\mathbf{u}}^{(d)}$ を用いて,

$$
\mathbf{u}^{(d)}=\overline{\mathbf{u}}^{(d)}\left(\xi^{(d)}, \eta^{(d)}, \zeta^{(d)}\right)
$$




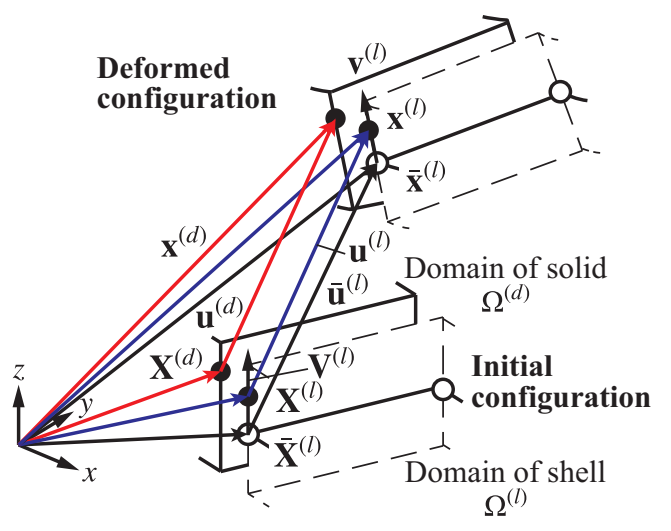

図-2 領域間境界における変位の接続

と表される.ここで， $\xi^{(d)}, \eta^{(d)}, \zeta^{(d)}$ は六面体要素で定 義されるアイソパラメトリック座標を意味する. 一方, シェル領域を退化シェル要素で離散化すると, 変位場 $\mathbf{u}^{(l)}$ は中央面に配置された節点の変位ベクトル $\overline{\mathbf{u}}^{(l)}$, 初 期配置, 現配置において節点で定義されるディレクター ベクトル $\mathbf{V}_{\Gamma}^{(l)}, \mathbf{v}_{\Gamma}^{(l)}$, 板厚 $h_{e}$ と, 節点の位置を基準とし て定義される面外方向の座標 $\zeta^{(l)}$ を用いて,

$$
\begin{aligned}
\mathbf{u}^{(l)}= & \overline{\mathbf{u}}^{(l)}\left(\xi^{(l)}, \eta^{(l)}\right) \\
& +\zeta^{(l)} \frac{h_{e}}{2}\left(\mathbf{v}_{\Gamma}^{(l)}\left(\xi^{(l)}, \eta^{(l)}\right)-\mathbf{V}_{\Gamma}^{(l)}\left(\xi^{(l)}, \eta^{(l)}\right)\right)
\end{aligned}
$$

と表現される，ここで，シェル要素で定義される板厚 $h_{e}$ は要素内で一定と仮定し $, \xi^{(l)}, \eta^{(l)}$ は面内方向に対す るアイソパラメトリック座標である.

図-2 に示すように，領域間境界 $\Gamma^{(d l)}$ における変位場 の連続性条件 (16) は, ソリッド要素の変位場 (19) と退 化シェル要素の変位場 (20) を用いて,

$$
\begin{array}{r}
\overline{\mathbf{u}}^{(d)}\left(\xi^{(d)}, \eta^{(d)}, \zeta^{(d)}\right) \\
=\overline{\mathbf{u}}^{(l)}\left(\xi^{(l)}, \eta^{(l)}\right)+\zeta^{(l)} \frac{h_{e}}{2}\left(\mathbf{v}_{\Gamma}^{(l)}\left(\xi^{(l)}, \eta^{(l)}\right)-\mathbf{V}_{\Gamma}^{(l)}\left(\xi^{(l)}, \eta^{(l)}\right)\right) \\
\text { on } \Gamma^{(d l)}
\end{array}
$$

と定義できる．変位場の連続性条件 (21) を線形化し，離 散化された後の節点自由度に対して適用すると, 複数 の節点変位を線形関係式として表現でき，一般的な多 点拘束条件 (Multiple Point Constraint, MPC） 2) が得ら れる.

\section{3. 領域間接続手法}

前節の定式化では，領域間境界における変位場の接 続条件 (16) は付帯条件として扱われる. しかし, 変位 場に対して制約条件を課すと, 領域間境界における力 のつりあい, すなわち, 応力ベクトルの連続性条件 (17) は，近似問題において満足されない。 そこで本研究で は, 変位ベクトルの連続性と応力ベクトルの連続性の 双方を考慮するために, 領域間境界における接続条件 に Nitsche 法を適用する。

\section{(1) Penalty 法}

変位場の接続条件 (16) からギヤップベクトル $\mathbf{g} を$

$$
\mathbf{g}=\mathbf{u}^{(d)}-\mathbf{u}^{(l)}
$$

と定義する. Penalty ポテンシャル $W^{\mathrm{P}}$ は, ギャップベ クトル $\mathbf{g}$ のノルムと Penalty 係数 $p$ を用いて,

$$
W^{\mathrm{P}}\left(\mathbf{u}^{(d)}, \mathbf{u}^{(l)}\right)=\int_{{ }^{0} \Gamma^{(d)}} \frac{p}{2} \mathbf{g} \cdot \mathbf{g} \mathrm{d} \Gamma
$$

と表せる. 式 (23) の Penalty ポテンシャル $W^{\mathrm{P}}$ を式 (18) の汎関数 Пに加えることで, Penalty 法に基づく汎関数 $\Pi^{\mathrm{P}}$ は,

$$
\Pi^{\mathrm{P}}\left(\mathbf{u}^{(d)}, \mathbf{u}^{(l)}\right)=\Pi\left(\mathbf{u}^{(d)}, \mathbf{u}^{(l)}\right)+W^{\mathrm{P}}\left(\mathbf{u}^{(d)}, \mathbf{u}^{(l)}\right)
$$

と定義できる．ここで，Penalty 係数 $p$ を十分大きな值 に設定することで，拘束条件が近似的に満足される。

\section{(2) Nitsche 法}

Nitsche 法では，変位ベクトルおよび応力ベクトルの 連続性が成立している状態において, 領域間境界におけ る表面力による仕事が 0 となることを以下の式で表す.

$\int_{{ }^{(} \Gamma^{(d)}} \mathbf{u}^{(d)} \cdot \boldsymbol{\sigma}^{(d)}\left(\mathbf{u}^{(d)}\right) \mathbf{n}^{(d)} \mathrm{d} \Gamma+\int_{{ }^{(} \Gamma^{(d)}} \mathbf{u}^{(l)} \cdot \boldsymbol{\sigma}^{(l)}\left(\mathbf{u}^{(l)}\right) \mathbf{n}^{(l)} \mathrm{d} \Gamma=0$

ここで, $\mathbf{n}^{(d)}, \mathbf{n}^{(l)}$ は現配置において領域間境界 $\Gamma^{(\mathrm{dl})}$ 上 で定義される単位法線ベクトルである. 現配置での領 域間境界で記述される関係式 (25) は, 初期配置を参照 することで，

$\int_{{ }^{0} \Gamma^{(d)}} \mathbf{u}^{(d)} \cdot \mathbf{P}^{(d)}\left(\mathbf{u}^{(d)}\right) \mathbf{N}^{(d)} \mathrm{d} \Gamma+\int_{{ }^{0} \Gamma^{(d l)}} \mathbf{u}^{(l)} \cdot \mathbf{P}^{(l)}\left(\mathbf{u}^{(l)}\right) \mathbf{N}^{(l)} \mathrm{d} \Gamma=0$

と表現できる。ここで， $\mathbf{P}^{(d)}$ はソリッド領域 $\Omega^{(d)}$ にお ける変位場 $\mathbf{u}^{(d)}$ から算出される 1st Piola-Kirchhoff 応力 テンソル, $\mathbf{P}^{(l)}$ はシェル領域 $\Omega^{(l)}$ における変位場 $\mathbf{u}^{(l)}$ か ら算出される 1st Piola-Kirchhoff 応力テンソルである. また, $\mathbf{N}^{(d)}$ はソリッド領域の境界 $\Gamma^{(d)}$ に対する外向き 単位法線ベクトル， $\mathbf{N}^{(l)}$ はシェル領域の境界 $\Gamma^{(l)}$ に対す る外向き単位法線ベクトルである. 式 (7) と同様に, 領 域間境界 ${ }^{0} \Gamma^{(d l)}$ 上における $\mathbf{N}^{(d)}, \mathbf{N}^{(l)}$ について,

$$
\mathbf{N}^{(d)}=-\mathbf{N}^{(l)}=\mathbf{N}
$$

の関係が成り立つ. 式(26)より, Nitsche ポテンシャル $W^{\mathrm{N}}$ は,

$$
W^{\mathrm{N}}\left(\mathbf{u}^{(d)}, \mathbf{u}^{(l)}\right)=-\int_{{ }^{0} \Gamma^{(d l)}}\left(\mathbf{u}^{(d)}-\mathbf{u}^{(l)}\right) \cdot([[\mathbf{P}]] \mathbf{N}) \mathrm{d} \Gamma
$$

と定義できる。ここで，

$$
[[\mathbf{P}]]=\alpha \mathbf{P}^{(d)}\left(\mathbf{u}^{(d)}\right)+(1-\alpha) \mathbf{P}^{(l)}\left(\mathbf{u}^{(l)}\right)
$$

であり， Nitsche パラメータ $\alpha$ は $0 \leq \alpha \leq 1$ をとる. 式 (28) の Nitsche ポテンシャル $W^{\mathrm{N}}$ を式 (24)の Penalty 法 に基づく汎関数 $\Pi^{\mathrm{P}}$ に追加することで, Nitsche 法に基 づく汎関数 $\Pi^{\mathrm{N}}$ を 


$$
\begin{aligned}
& \Pi^{\mathrm{N}}\left(\mathbf{u}^{(d)}, \mathbf{u}^{(l)}\right)=\Pi^{\mathrm{P}}\left(\mathbf{u}^{(d)}, \mathbf{u}^{(l)}\right)+W^{\mathrm{N}}\left(\mathbf{u}^{(d)}, \mathbf{u}^{(l)}\right) \\
& =\Pi\left(\mathbf{u}^{(d)}, \mathbf{u}^{(l)}\right) \\
& +W^{\mathrm{P}}\left(\mathbf{u}^{(d)}, \mathbf{u}^{(l)}\right)+W^{\mathrm{N}}\left(\mathbf{u}^{(d)}, \mathbf{u}^{(l)}\right) \\
& =\int_{{ }^{\Omega^{(d)}}} W^{(d)}\left(\mathbf{F}^{(d)}\right) \mathrm{d} \Omega \\
& -\int_{{ } \Omega^{(d)}} \mathbf{u}^{(d)} \cdot \mathbf{b}^{(d)} \mathrm{d} \Omega-\int_{{ }^{\top} \Gamma^{(d)}} \mathbf{u}^{(d)} \cdot \overline{\mathbf{t}}^{(d)} \mathrm{d} \Gamma \\
& +\int_{\Omega^{(l)}} W^{(l)}\left(\mathbf{F}^{(l)}\right) \mathrm{d} \Omega \\
& -\int_{{ }^{(} \Omega^{(l)}} \mathbf{u}^{(l)} \cdot \mathbf{b}^{(l)} \mathrm{d} \Omega-\int_{{ }^{(} \Gamma^{(l)}} \mathbf{u}^{(l)} \cdot \overline{\mathbf{t}}^{(l)} \mathrm{d} \Gamma \\
& +\int_{{ }^{0} \Gamma^{(d l)}} \frac{p}{2} \mathbf{g} \cdot \mathbf{g} \mathrm{d} \Gamma \\
& -\int_{{ }^{\Gamma} \Gamma^{(d l)}}\left(\mathbf{u}^{(d)}-\mathbf{u}^{(l)}\right) \cdot([[\mathbf{P}]] \mathbf{N}) \mathrm{d} \Gamma
\end{aligned}
$$

と定義する.ここで, 式(28)で定義される Nitsche ポテ ンシャルに式 (22) のギャップベクトル $\mathbf{g}$ が含まれてい ることから, Nitsche 法に基づく定式化では Penalty ポ テンシャルと Nitsche ポテンシャルによって, 変位に対 する拘束条件が課される.

Nitsche 法に基づく汎関数 $\Pi^{\mathrm{N}}$ の $\mathbf{u}^{(d)}$ についての変分 をとることで, ソリッド領域 $\Omega^{(d)}$ での仮想仕事に対応 した弱形式は，

$$
\begin{aligned}
G^{(d)} & \left(\mathbf{u}^{(d)}, \mathbf{u}^{(l)} ; \delta \mathbf{u}^{(d)}\right) \\
= & \int_{{ }^{0} \Omega^{(d)}} \mathbf{S}^{(d)}\left(\mathbf{u}^{(d)}\right): \mathbf{E}\left(\delta \mathbf{u}^{(d)}\right) \mathrm{d} \Omega \\
& -\int_{\Omega^{(d)}} \mathbf{b}^{(d)} \cdot \delta \mathbf{u}^{(d)} \mathrm{d} \Omega-\int_{{ }^{(d)}} \overline{\mathbf{t}}^{(d)} \cdot \delta \mathbf{u}^{(d)} \mathrm{d} \Gamma \\
& +\int_{\Gamma^{(d l)}} \delta \mathbf{u}^{(d)} \cdot\left\{p\left(\mathbf{u}^{(d)}-\mathbf{u}^{(l)}\right)-[[\mathbf{P}]] \mathbf{N}\right\} \mathrm{d} \Gamma \\
& -\int_{{ }^{0}(d l)}\left(\mathbf{u}^{(d)}-\mathbf{u}^{(l)}\right) \cdot \alpha \mathbf{P}^{(d)}\left(\delta \mathbf{u}^{(d)}\right) \mathbf{N} \mathrm{d} \Gamma
\end{aligned}
$$

となる. 同様に, Nitsche 法に基づく汎関数 $\Pi^{\mathrm{N}}$ の $\mathbf{u}^{(l)}$ についての変分をとると, シェル領域 $\Omega^{(l)}$ での仮想仕 事に対応した弱形式

$$
\begin{aligned}
G^{(l)} & \left(\mathbf{u}^{(d)}, \mathbf{u}^{(l)} ; \delta \mathbf{u}^{(l)}\right) \\
= & \int_{{ }^{0} \Omega^{(l)}} \mathbf{S}^{(l)}\left(\mathbf{u}^{(l)}\right): \mathbf{E}\left(\delta \mathbf{u}^{(l)}\right) \mathrm{d} \Omega \\
& -\int_{\Omega^{(l)}} \mathbf{b}^{(l)} \cdot \delta \mathbf{u}^{(l)} \mathrm{d} \Omega-\int_{{ }^{(l)}} \overline{\mathbf{t}}^{(l)} \cdot \delta \mathbf{u}^{(l)} \mathrm{d} \Gamma \\
& -\int_{{ }^{0} \Gamma^{(d)}} \delta \mathbf{u}^{(l)} \cdot\left\{p\left(\mathbf{u}^{(d)}-\mathbf{u}^{(l)}\right)-[[\mathbf{P}]] \mathbf{N}\right\} \mathrm{d} \Gamma \\
& -\int_{{ }^{\Gamma^{(d)}}}\left(\mathbf{u}^{(d)}-\mathbf{u}^{(l)}\right) \cdot(1-\alpha) \mathbf{P}^{(l)}\left(\delta \mathbf{u}^{(l)}\right) \mathbf{N} \mathrm{d} \Gamma
\end{aligned}
$$

が得られる。ここで， $\delta \mathbf{u}^{(d)} ， \delta \mathbf{u}^{(l)}$ はそれぞれ $\mathbf{u}^{(d)}, \mathbf{u}^{(l)}$ の変分である. 式(31), (32)の仮想仕事式から導出され る節点変位に関する連立方程式の係数行列は, Nitsche パラメータ $\alpha$ が 0.5 の場合を除いて非対称行列となる.

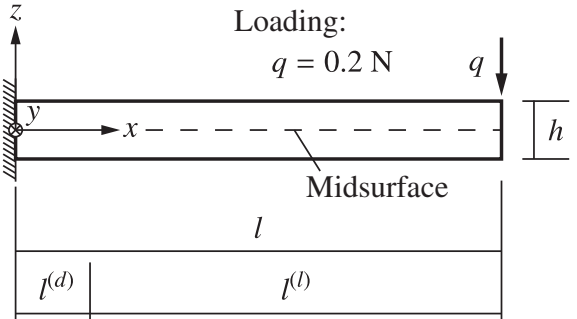

Plane strain condition in $y$ direction

$$
\begin{array}{rlrl}
\text { Geometry: } & \text { Material: } & \\
h=1 \mathrm{~mm} & E & =1.0 \times 10^{2} \mathrm{~N} / \mathrm{mm}^{2} \\
l & =20 \mathrm{~mm} & v & =0.3
\end{array}
$$

図-3 片持ちはりの数值計算モデル

\section{4. 有限要素近似}

本研究では，シェル領域の離散化に Reissner-Mindlin の定式化に基づく退化シェル要素3), ソリッド領域の離 散化には六面体 1 次要素を用いる. シェル要素につい ては, 退化シェル要素で生じるせん断ロッキングを回 避した MITC4 シェル要素14)を採用する.

\section{5. 数值計算例}

本章では数值計算例により, 提案するモデル化手法 を検証する。ここで, 材料構成則としてシェル要素と ソリッド要素に対して, St. Venant-Kirchhoff 材料モデ ルを用いる，ただし，シェル要素については，面外方 向に平面応力状態が仮定される.

前節までの定式化において, 領域間境界での境界積 分に関するメッシュ分割の制約は存在しない. 本例題 では, 接続部分でのシェル要素とソリッド要素の節点 の位置および面内方向に対するメッシュ分割数を一致 させ，シェル要素のレイヤー数に合わせてソリッド要 素の面外方向に対するメッシュ分割数を設定する.

\section{(1) 片持ちはりの曲げ解析}

本研究で提案するモデル化手法について, 図-3に示 す片持ちはりを用いて検証する。ここでは接続部分の 力学状態に着目するため, 境界条件として奥行き方向 （ $y$ 方向）を平面ひずみ状態とする.

図-3において， $l^{(d)} ， l^{(l)}$ はそれぞれ，ソリッド領域， シェル領域の長さを表す.ソリッド要素とシェル要素 を接続したモデル $\left(l^{(d)}=1[\mathrm{~mm}], l^{(l)}=19[\mathrm{~mm}]\right)$ と ソリッド要素のみで離散化したモデル $\left(l^{(d)}=20[\mathrm{~mm}]\right.$, $\left.l^{(l)}=0[\mathrm{~mm}]\right)$ を比較する. モデルの離散化では， $x$ 方 向に対してソリッド要素のメッシュ長さを $0.25[\mathrm{~mm}]$, シェル要素のメッシュ長さを $1[\mathrm{~mm}]$ とし, $z$ 方向に対 するソリッド要素の分割数とシェル要素のレイヤー数 は 10 とする。 

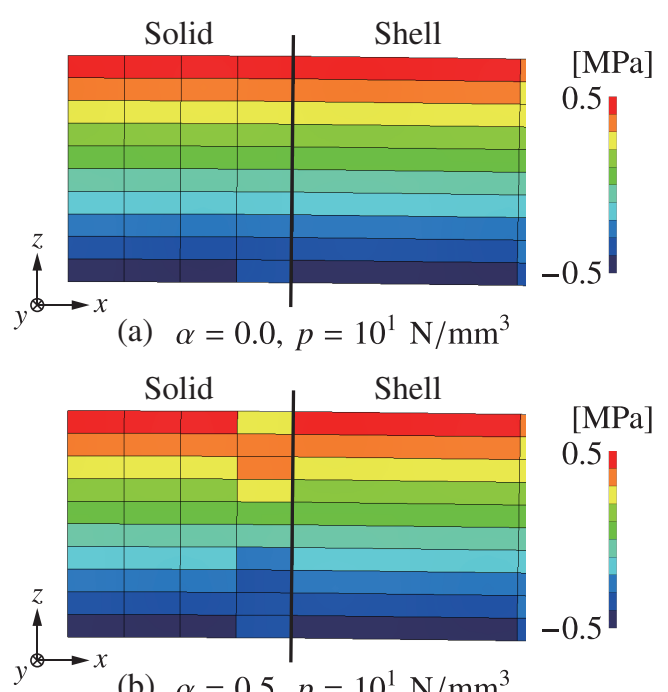

(b) $\alpha=0.5, p=10^{1} \mathrm{~N} / \mathrm{mm}^{3}$

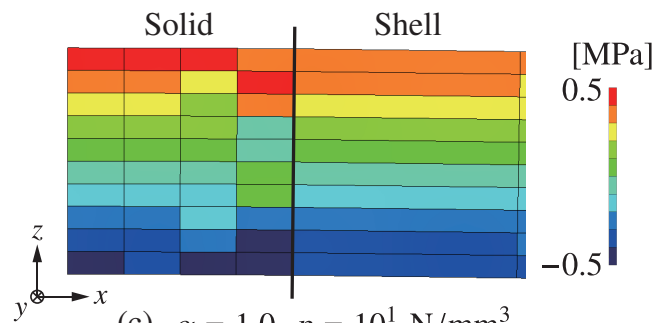

(c) $\alpha=1.0, p=10^{1} \mathrm{~N} / \mathrm{mm}^{3}$
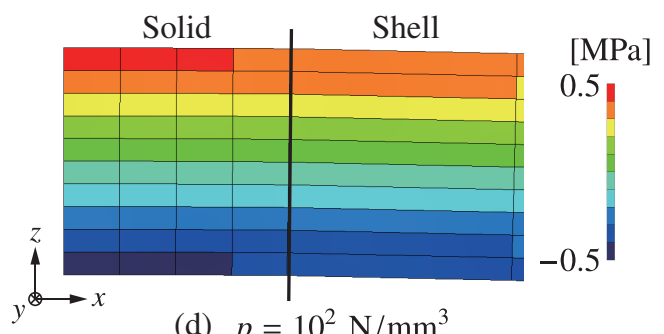

(d) $p=10^{2} \mathrm{~N} / \mathrm{mm}^{3}$

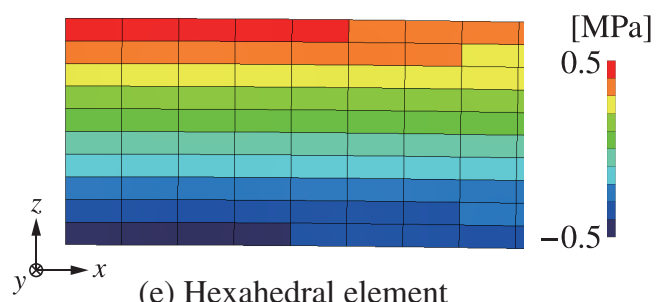

図-4 $x$ 方向垂直応力の分布 $(q: 0.004 \mathrm{~N})$

$x=0$ の面から領域間境界近傍までの Cauchy 応力の 分布について，微小変形に対する計算結果を図 $\mathbf{4 , 5}$, 有限変形に対する計算結果を図-6,7 に示す. Nitsche 法 に基づく定式化は，Nitsche ポテンシャルによって変位 に対する拘束条件が追加されることから, Penalty 係数 $p$ の值を小さく設定できることが特長である。そのた め, Penalty 係数 $p=10^{1}\left[\mathrm{~N} / \mathrm{mm}^{3}\right]$ として Nitsche 法を 適用した計算結果, Penalty 係数 $p=10^{2}\left[\mathrm{~N} / \mathrm{mm}^{3}\right]$ とし た Penalty 法の夕の計算結果，六面体要素のみで離散化 したモデルの計算結果を比較する．Penalty 係数は剛性 を要素代表長さで除した值であり，本例題の領域間境界 での要素代表長さが 1 [mm]であることから, Penalty 係
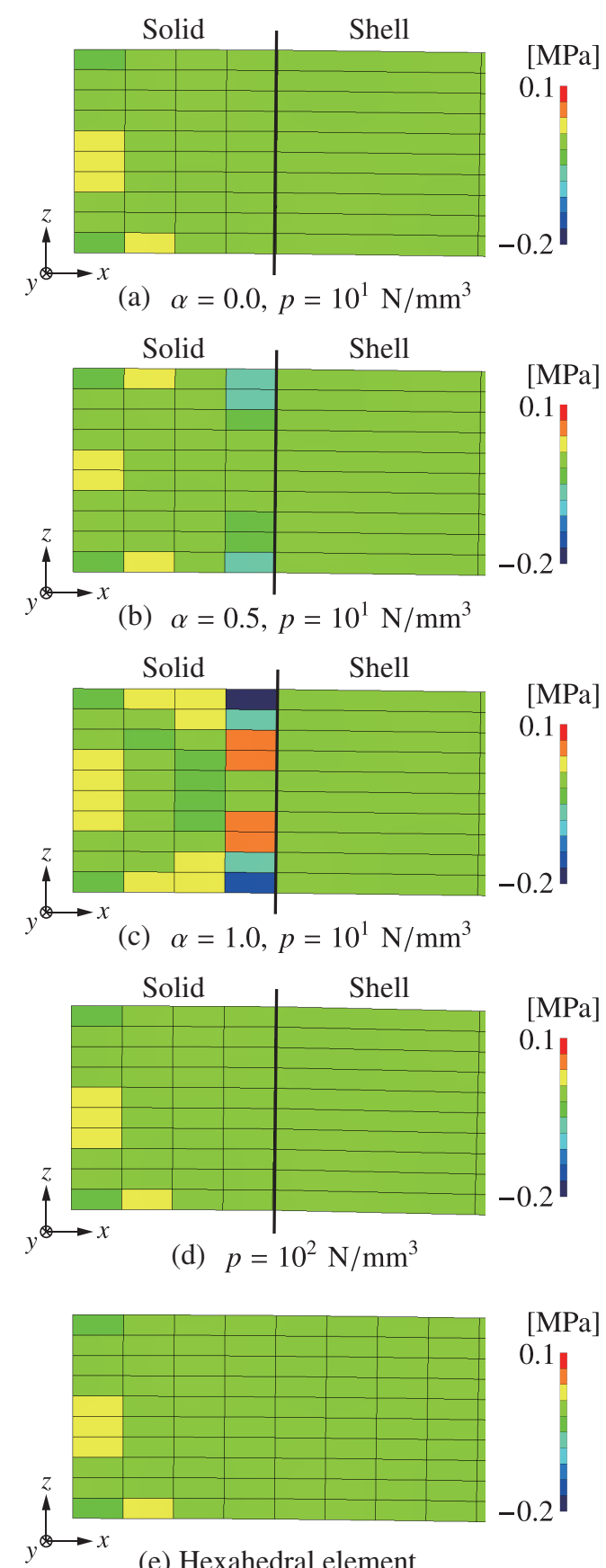

図-5 面外せん断応力の分布 $(q$ : $0.004 \mathrm{~N})$

数は接続部分の剛性を意味する. 図-4,5 から, Penalty 法と Nitsche 法 $(\alpha=0.0)$ の計算結果が六面体要素の計 算結果と同様であることが確認できる。一方， $\alpha \neq 0.0$ を適用した Nitsche 法では，領域間境界近傍において不 自然な応力状態が生じる.

図-4, 5 に示寸計算結果の特徵から, Nitsche 法に基づ く接続手法の概要が説明できる. Penalty 法による接続 では，領域間境界において変位に対する強い拘束条件が 課される，そこで，Penalty 法の安定化項として Nitsche 法を追加することで応力ベクトルの連続性が考慮され， 領域間境界での変位に対する拘束条件が緩和される。 Nitsche 法においてシェル領域の応力ベクトルを採用す 


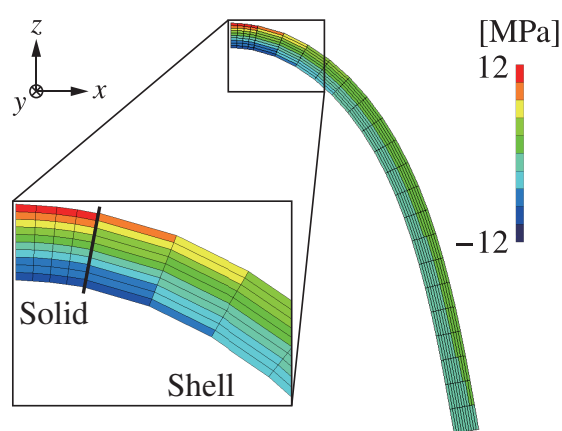

(a) $\alpha=0.0, p=10^{1} \mathrm{~N} / \mathrm{mm}^{3}$

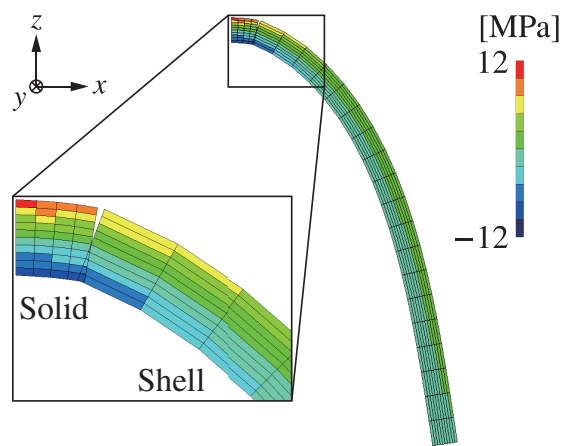

(b) $p=10^{2} \mathrm{~N} / \mathrm{mm}^{3}$

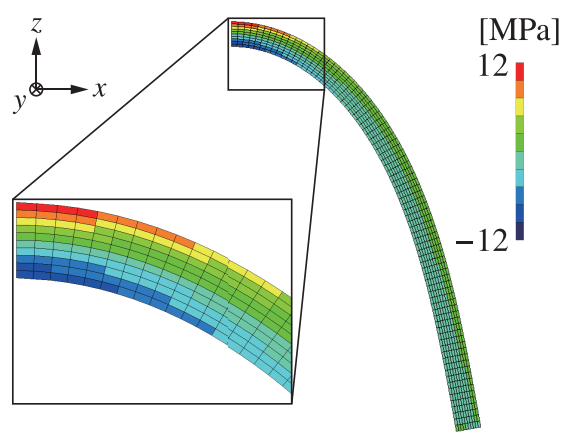

(c) Hexahedral element

図-6 $x$ 方向垂直応力の分布 $(q: 0.2 \mathrm{~N})$

る場合 $(\alpha=0.0)$, シェル領域の境界を基準として領域 間境界の変位に対する拘束条件が課される。このとき， シェル領域の境界はシェル要素の節点の位置ベクトル およびディレクターベクトルによって定義され，領域間 境界に接する六面体要素はシェル要素のディレクターベ クトルに沿って変形する。一方， Nitsche 法においてソ リッド領域の応力ベクトルを採用する場合 $(\alpha=1.0)$, ソリッド領域の境界を基準として領域間境界の変位に 対する拘束条件が課される。このとき，ソリッド領域の 境界は領域間境界に接するソリッド要素の節点の位置 ベクトルで定義され，領域間境界でのシェル要素は接 続に関与する六面体要素の各節点の位置ベクトルの平 均として表現される境界に沿って変形する。そのため, $\alpha \neq 0.0$ を採用した Nitsche 法では，ソリッド領域の境 界に属する六面体要素の節点に対する拘束条件が過度 に緩和され，境界が一意に定まらない数值的な不安定



(a) $\alpha=0.0, p=10^{1} \mathrm{~N} / \mathrm{mm}^{3}$

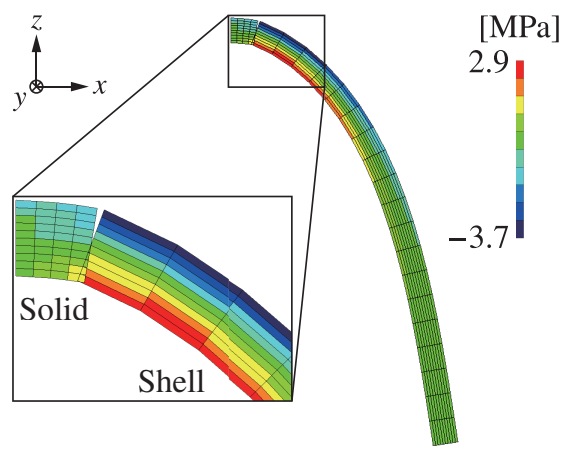

(b) $p=10^{2} \mathrm{~N} / \mathrm{mm}^{3}$

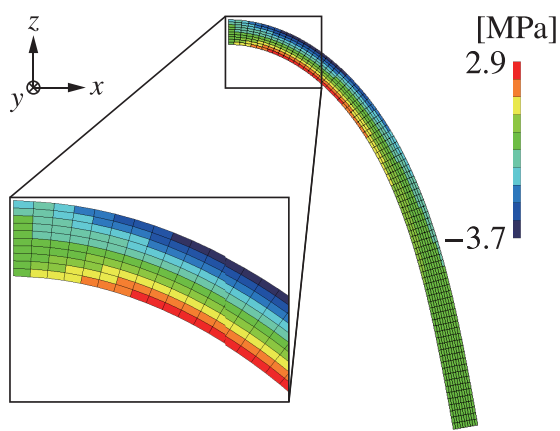

(c) Hexahedral element

図-7 面外せん断応力の分布 $(q: 0.2 \mathrm{~N})$

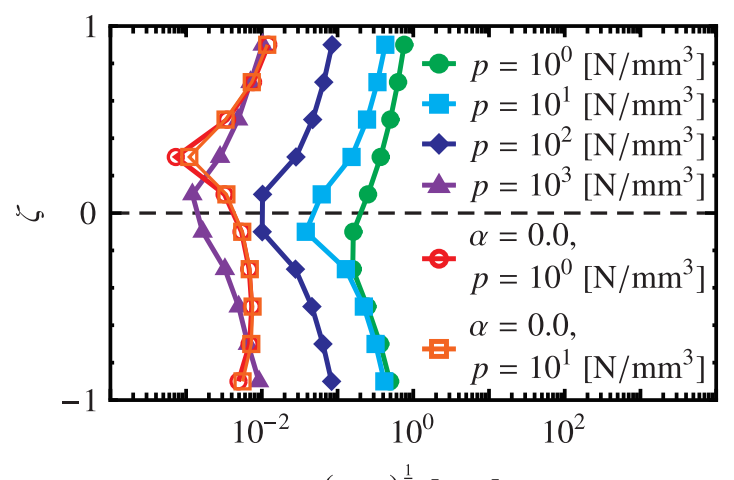

$(\mathbf{g} \cdot \mathbf{g})^{\frac{1}{2}}[\mathrm{~mm}]$

図-8 領域間境界における変位の連続性（片持ちはり, $q: 0.2 \mathrm{~N}$ )

性を示す.この特徵は, 本例題で扱った 2 次元問題（平 面ひずみ問題）のみならず，3 次元問題においても確認 されており， Nitsche 法を適用した数值計算における不 安定性といえる。したがって, MITC4 シェル要素と六 
表-1 先端における変位の比較（片持ちはり，q: $0.2 \mathrm{~N}$ )

\begin{tabular}{ccc}
\hline & $x$-dir. [mm] & $z$-dir. [mm] \\
\hline Nitsche's method & -10.536 & -15.957 \\
Penalty method & -11.402 & -16.647 \\
Solid & -10.465 & -15.931 \\
\hline
\end{tabular}

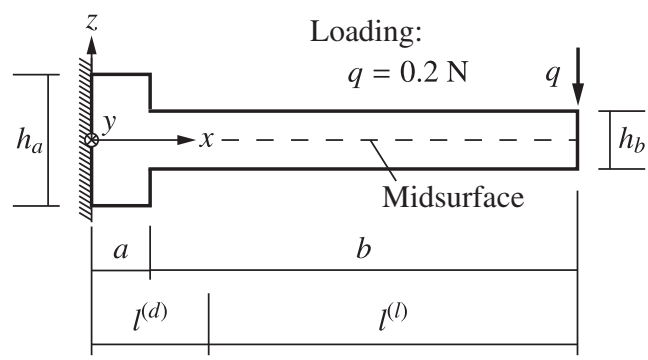

Plane strain condition in $y$ direction

$$
\begin{array}{clc}
\text { Geometry: } & \multicolumn{2}{c}{\text { Material: }} \\
h_{a}=3 \mathrm{~mm} & a=1 \mathrm{~mm} & E=1.0 \times 10^{2} \mathrm{~N} / \mathrm{mm}^{2} \\
h_{b}=1 \mathrm{~mm} & b=19 \mathrm{~mm} & v=0.3
\end{array}
$$

図-9 段付きはりの数值計算モデル

面体 1 次要素の接続に Nitsche 法を適用する場合には, $\alpha=0.0$ と設定することで安定的な数值計算を実現でき る。以降の検証では， $\alpha=0.0$ を適用した Nitsche 法の 計算結果について考察する.

有限変形に対して，図-6,7 に示した Penalty 法の計算 結果では，領域間境界において変位が適切に接続されて いない.ここで，領域間境界におけるギャップベクトル のノルムを比較したものを図-8に示す．図中の縦軸は 領域間境界での面外方向に対する座標，横軸はギャップ ベクトルのノルムを意味する. 図-8 の Penalty 法の計算 結果に着目すると, Penalty 係数として大きな值を設定 することで，ギャップベクトルのノルムが小さくなる. そのため, 上述の変位に対する連続性は, Penalty 係数 をより大きな值に設定することで改善できるが，数值計 算モデルの一部に大きな剛性を与えることは適切なモ デル化とはいえない，それに対して，Nitsche 法の計算 結果は Penalty 係数を小さな值に設定した場合でも，変 位に対する連続性が十分に満足される。しかしながら, Nitsche 法は Penalty 係数の值によって変位ベクトルお よび応力ベクトルに対する連続性が制御される。した がって, Nitsche 法を適用する際の Penalty 係数は, ヤン グ率を要素代表長さで除した值に比べて小さく設定する ことが望ましい，その条件下において，Nitsche 法は有 限変形に対して領域間境界が適切に接続され，表-1 の ように六面体要素と同様の計算結果が得られる。

\section{（2）段付きはりの曲げ解析}

図-9に示す段付きはりを用いて，本研究で提案する モデル化手法の適用範囲を検証する. 本例題は, シェル

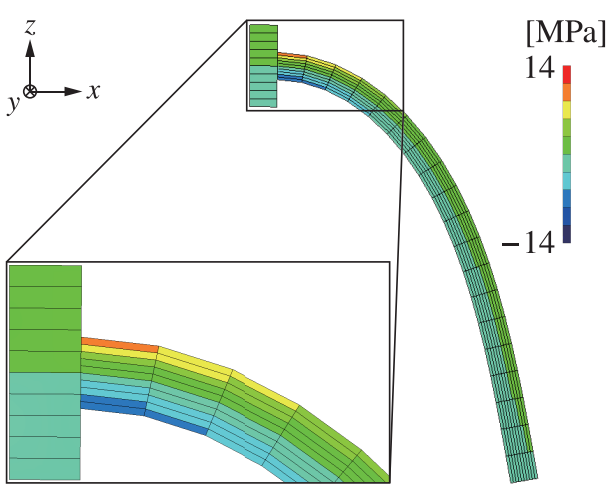

(a) MITC4 shell element

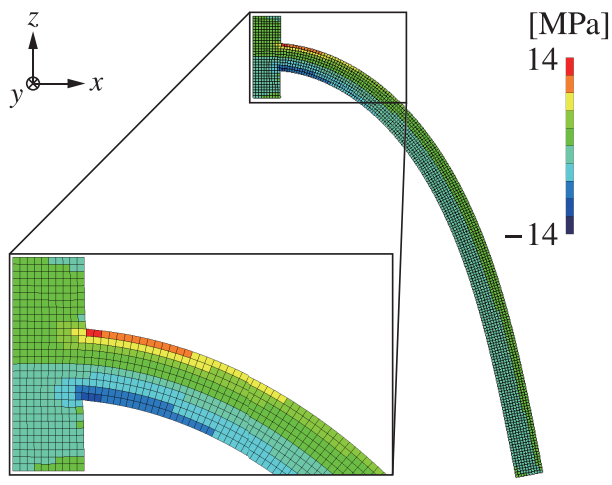

(b) Hexahedral element

図-10 $x$ 方向垂直応力の分布（段付きはり）

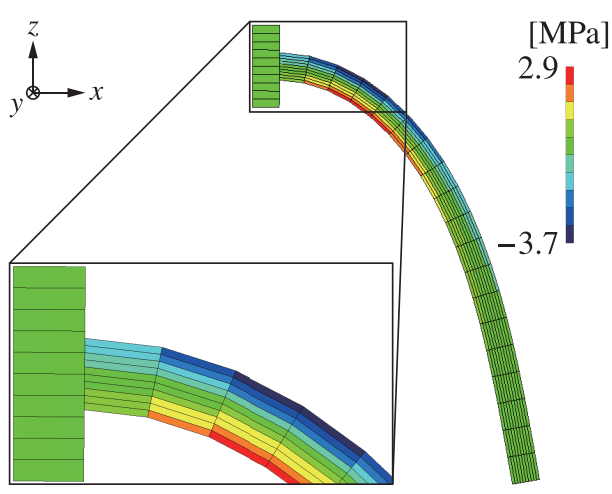

(a) MITC4 shell element

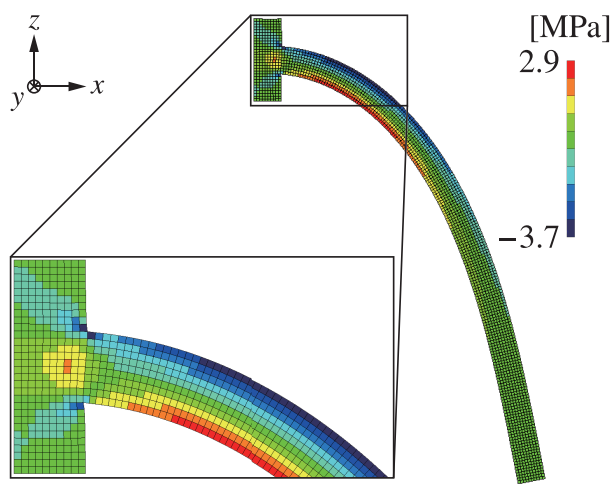

(b) Hexahedral element

図-11 面外せん断応力の分布（段付きはり） 
表-2 先端における変位の比較（段付きはり）

\begin{tabular}{ccc}
\hline & $x$-dir. [mm] & $z$-dir. [mm] \\
\hline Nitsche's method & -9.9166 & -15.291 \\
Penalty method & -10.726 & -15.900 \\
Solid & -9.9140 & -15.293 \\
\hline
\end{tabular}

要素によるモデル化では適切な数值解が得られない状 沉を想定する.

図-9において， $l^{(d)} ， l^{(l)}$ はそれぞれ，ソリッド領域, シェル領域の長さであり, ソリッド要素とシェル要素 を接続したモデル $\left(l^{(d)}=2[\mathrm{~mm}], l^{(l)}=18[\mathrm{~mm}]\right)$ と ソリッド要素のみで離散化したモデル $\left(l^{(d)}=20[\mathrm{~mm}]\right.$, $\left.l^{(l)}=0[\mathrm{~mm}]\right)$ を比較する. モデルの離散化では, $x$ 方向, $z$ 方向に対するソリッド要素のメッシュ長さを $0.1[\mathrm{~mm}]$ とし，シェル要素のメッシュ長さを $1[\mathrm{~mm}]$, レイヤー 数を 10 と設定する.

まず，図-9をシェル要素のみで離散化したモデル $\left(l^{(d)}=0[\mathrm{~mm}], l^{(l)}=20[\mathrm{~mm}]\right)$, ソリッド要素のみ で離散化したモデル $\left(l^{(d)}=20[\mathrm{~mm}], l^{(l)}=0[\mathrm{~mm}]\right)$ に ついて，モデル全体と固定端から段付き部分近傍まで の変形図および Cauchy 応力の分布を図-10,11 に示す.

図-10,11 から，局所的な力学挙動の評価には，ソリッ ド要素によるモデル化が適切であることが確認できる. また，シェル要素によるモデル化では，図-9での断面 全体を完全固定する境界条件を扱うことは困難であり， 境界条件として中央面のみが固定される.

次に, ソリッド要素とシェル要素を接続したモデル $\left(l^{(d)}=2[\mathrm{~mm}], l^{(l)}=18[\mathrm{~mm}]\right)$ での変形図および Cauchy 応力の分布を図-12,13 に示寸. 図-12,13 では, Penalty 法の計算結果は六面体要素のみで離散化したモ デルの計算結果に近い応力分布が得られるが，ソリッド 領域とシェル領域の領域間境界でソリッド要素とシェル 要素の境界が一致せず，変位が適切に接続されていな い。それに対して, Nitsche 法ではソリッド要素とシェ ル要素の境界が一致し，六面体要素のみで離散化した モデルの計算結果と同様の応力分布が得られる。 また, 段付き部分をソリッド領域としてモデル化することで, 応力集中が適切に評価できる.したがって，本研究で 提案するモデル化手法では, 局所的な力学挙動を評価 する部分にソリッド要素を適用することで, 精度の高 い数值計算結果が得られる。この特徵は, 表-2 に示す 計算結果の傾向と一致する.

\section{(3) 平板の曲げ解析}

図-14のような平板の曲げ問題を用いて，提案するモ デル化手法の妥当性を検証する. 図-14に対して,ソリ

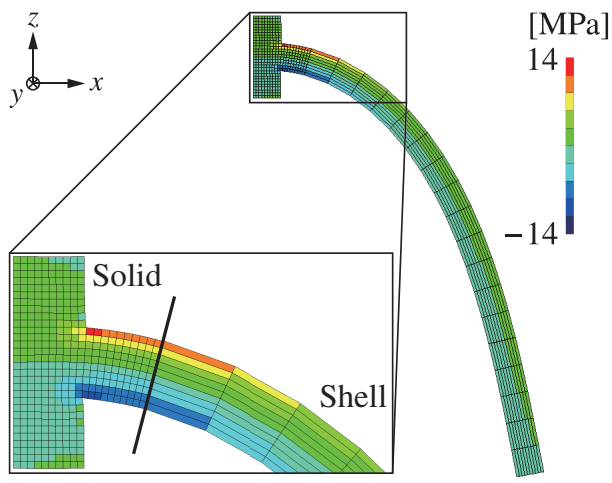

(a) $\alpha=0.0, p=10^{1} \mathrm{~N} / \mathrm{mm}^{3}$

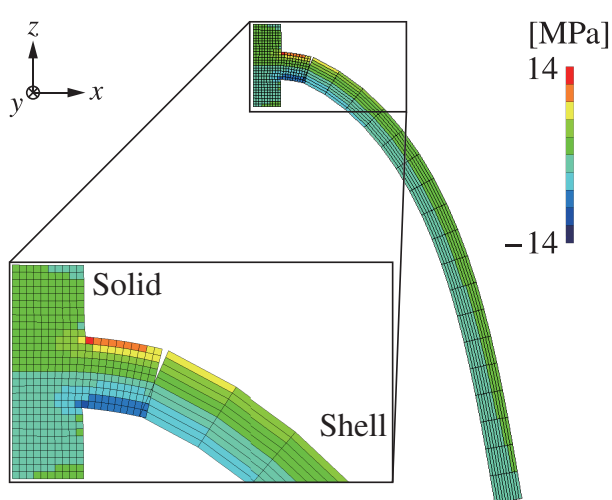

(b) $p=10^{2} \mathrm{~N} / \mathrm{mm}^{3}$

図-12 $x$ 方向垂直応力の分布 $\left(l^{(d)}=2 \mathrm{~mm}, l^{(l)}=18 \mathrm{~mm}\right)$

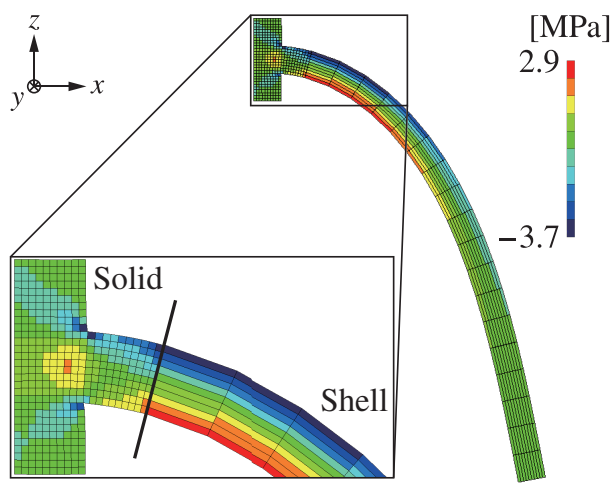

(a) $\alpha=0.0, p=10^{1} \mathrm{~N} / \mathrm{mm}^{3}$

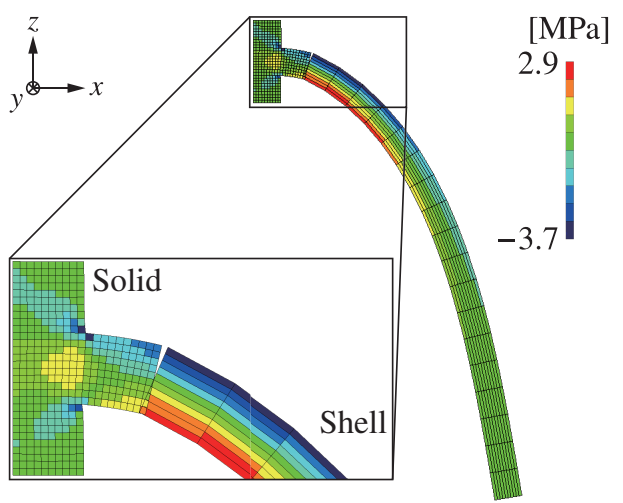

(b) $p=10^{2} \mathrm{~N} / \mathrm{mm}^{3}$

図-13 面外せん断応力の分布 $\left(l^{(d)}=2 \mathrm{~mm}, l^{(l)}=18 \mathrm{~mm}\right)$ 


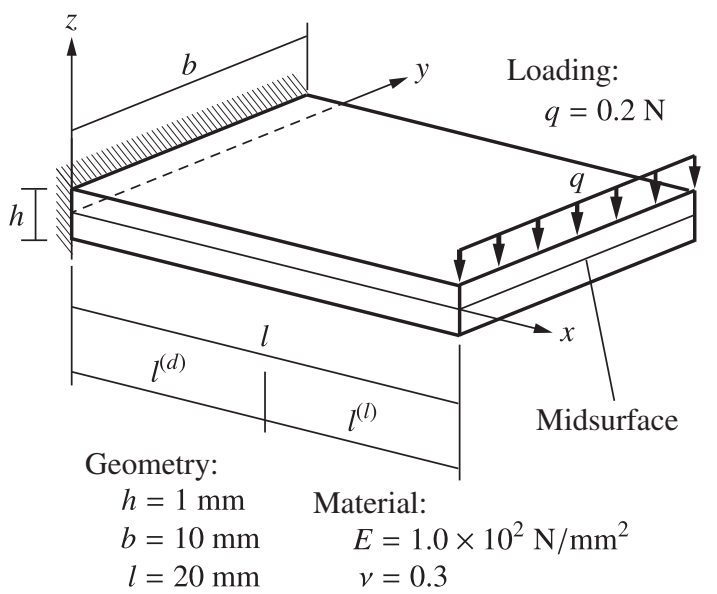

図-14 平板の数值計算モデル

ッド要素とシェル要素を接続したモデル $\left(l^{(d)}=10[\mathrm{~mm}]\right.$, $\left.l^{(l)}=10[\mathrm{~mm}]\right)$ とソリッド要素のみで離散化したモデ ル $\left(l^{(d)}=20[\mathrm{~mm}], l^{(l)}=0[\mathrm{~mm}]\right)$ を比較する. モデル の離散化では, $x$ 方向に対してソリッド要素のメッシュ 長さを $0.5[\mathrm{~mm}]$, シェル要素のメッシュ長さを $1[\mathrm{~mm}]$, $y$ 方向に対するメッシュ長さをそれぞれ， $1[\mathrm{~mm}]$ とし， $z$ 方向に対するソリッド要素の分割数とシェル要素のレ イヤー数は 10 とする.

平板の変形図およびCauchy 応力の分布を図-15, 16 に 示す.ここでは, Penalty 係数 $p=10^{0}\left[\mathrm{~N} / \mathrm{mm}^{3}\right]$ として Nitsche 法 $(\alpha=0.0)$ を適用した計算結果, Penalty 係 数 $p=10^{2}\left[\mathrm{~N} / \mathrm{mm}^{3}\right]$ とした Penalty 法のみの計算結果, 六面体要素のみで離散化したモデルの計算結果を比較 する. Penalty 係数は剛性を要素代表長さで除した值で あり，本例題の領域間境界での要素代表長さは $1[\mathrm{~mm}]$ であるため, Penalty 係数の值を接続部分の剛性とみな せる．図-15,16では，Nitsche 法を適用した計算結果お よび Penalty 法のみの計算結果において，領域間境界近 傍に不自然な応力分布がみられる。これは，曲げ変形 と反り変形によって面内方向に複雑な応力状態が生じ るためであると考えられる。このような応力状態に対 応した接合を実現するには，領域間境界近傍における メッシュの解像度などを検討する必要がある。

3 次元の力学挙動に対して提案するモデル化手法の有 用性を確認するために，平板の先端における中央およ び隅での変位を表-3,4にまとめる. Penalty 法の計算結 果に比べて, Nitsche 法を適用することで六面体要素と 同様の変形状態が得られることが確認できる．このこ とから, 大域的な変形については, 図-15,16での忘力 状態の相違による影響が小さいといえる。また，本例 題で生じる変形は微小であるが, 変形量が大きくなり 幾何学的非線形性が強くなるにつれて, 片持ちはりの 曲げ解析に対する検証で示したように, Nitsche 法の適 用が有用となる.

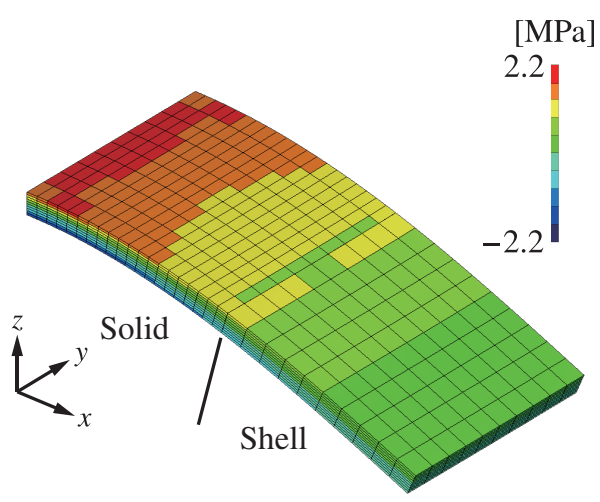

(a) $\alpha=0.0, p=10^{0} \mathrm{~N} / \mathrm{mm}^{3}$

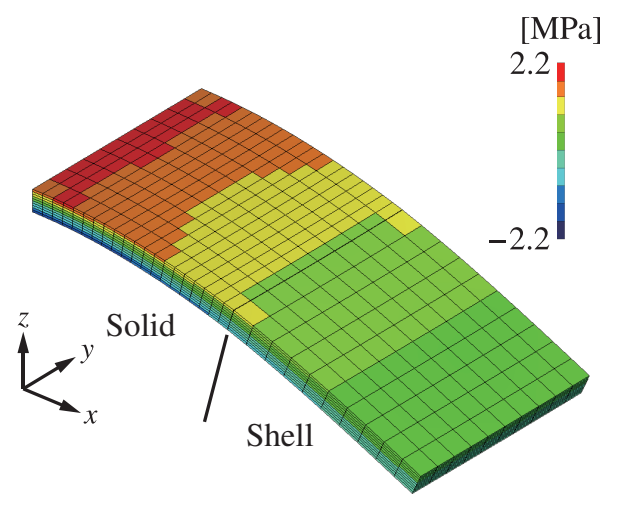

(b) $p=10^{2} \mathrm{~N} / \mathrm{mm}^{3}$

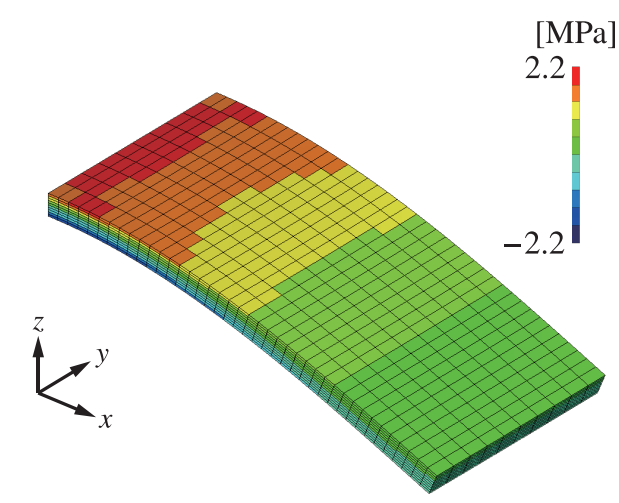

(c) Hexahedral element

図-15 $x$ 方向垂直応力の分布 (平板)

表-3 先端（中央）における変位の比較（平板）

\begin{tabular}{ccc}
\hline & $x$-dir. [mm] & $z$-dir. [mm] \\
\hline Nitsche's method & -0.85681 & -5.2540 \\
Penalty method & -0.93015 & -5.4344 \\
Solid & -0.83172 & -5.1926 \\
\hline
\end{tabular}

表-4 先端（隅）における変位の比較（平板）

\begin{tabular}{ccc}
\hline & $x$-dir. [mm] & $z$-dir. [mm] \\
\hline Nitsche's method & -0.84686 & -5.2292 \\
Penalty method & -0.91983 & -5.4100 \\
Solid & -0.82582 & -5.1744 \\
\hline
\end{tabular}




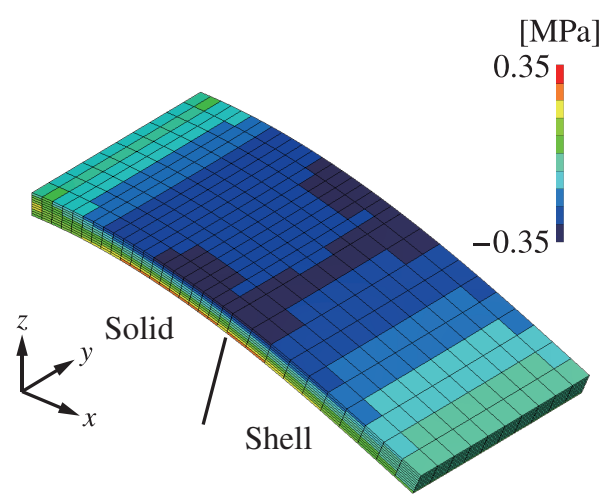

(a) $\alpha=0.0, p=10^{0} \mathrm{~N} / \mathrm{mm}^{3}$

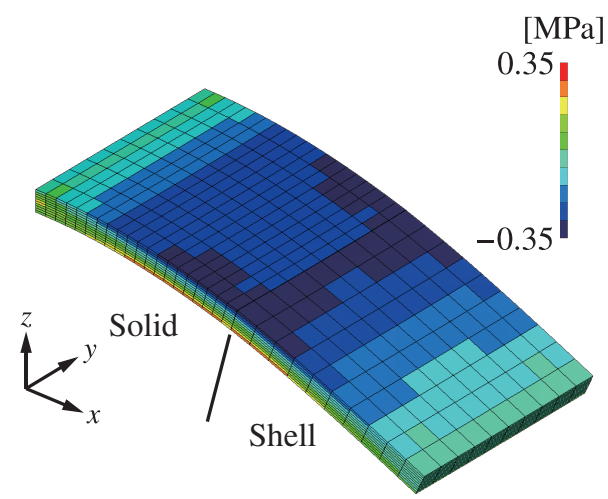

(b) $p=10^{2} \mathrm{~N} / \mathrm{mm}^{3}$

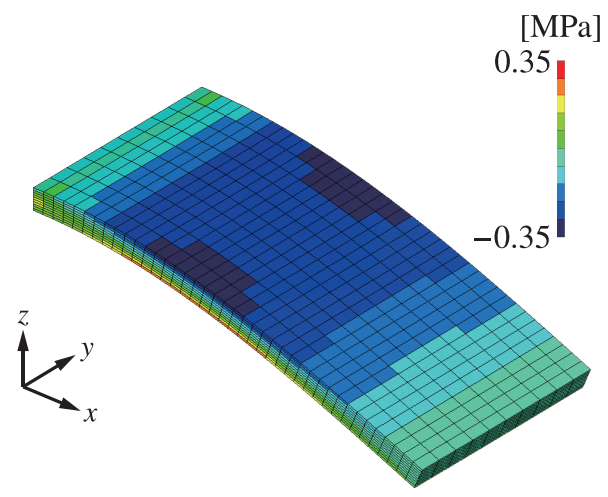

(c) Hexahedral element

図-16 面外せん断応力の分布（平板）

\section{6. おわりに}

本研究では, Penalty 法による変位の連続性と Nitsche 法に基づく応力ベクトルの連続性を考慮することで, シェル要素とソリッド要素を接続するモデル化手法を 提案した. 本手法は領域分割に基づく定式化において, ソリッド領域とシェル領域に対する全ポテンシャルエ ネルギー汎関数を定義し, 変位に関する連続性として Penalty ポテンシャル, 応力ベクトルの連続性を考慮す るために Nitsche ポテンシャルを追加することで, 領域 全体におけるポテンシャルエネルギー汎関数の最小化 問題を定義した。数值計算例により，シェル要素とソ リッド要素の接続部分近傍において, ソリッド要素の
みでモデル化した場合と同様の応力分布が得られ，変 位の連続性のみを考慮する従来の手法では得られない 計算結果を示した。本手法の適用範囲として，接続部 分の板厚に対する制約は存在しない。ただし，曲げに よってせん断変形が卓越する問題では板厚が厚いほど 面外せん断変形が顕著となるため, 局所的な力学挙動 が評価できるようにシェル領域とソリッド領域の大き さを適切に設定する必要がある.今後は，矩形板の角 部などの複雑な応力状態が確認される問題に提案手法 を適用し，モデル化の妥当性を検証するとともに，適 用範囲を拡張していく予定である.

\section{参考文献}

1) W. Jialin, L. Zhiwen, M. Xing, Z. Jianzheng: A DOF expanding method for connecting solid and shell element, Commun. Numer. Methods Eng., Vol.12, pp.321-330, 1996.

2) G. R. Liu, S. S. Quek: The Finite Element Method: A Practical Course, 2nd ed., Butterworth-Heinemann, 2013.

3) K. J. Bathe: Finite Element Procedure, Prentice-Hall, Inc., Upper Saddle River, New Jersey, 1996.

4) K. S. Surana: Transition finite elements for three-dimensional stress analysis, Int. J. Numer. Methods Eng., Vol.15, pp.991-1020, 1980.

5) D. J. Monaghan, I. W. Doherty, D. M. Court, C. G. Armstrong: Coupling 1D beams to 3D bodies, 7th International Meshing Roundtable, Sandia National Laboratories, Dearborn, Michigan, 1998.

6) A. Hansbo, P. Hansbo: An unfitted finite element method, based on Nitsche's method, for elliptic interface problems, Comput. Methods Appl. Mech. Eng., Vol.191, pp.55375552, 2002.

7) A. Fritz, S. Hüeber, B. I. Wohlmuth: A comparison of mortar and Nitsche techniques, CALCOLO, Vol.41, pp.115137, 2004.

8) J. D. Sanders, M. A. Puso: An embedded mesh method for treating overlapping finite element meshes, Int. J. Numer. Methods Eng., Vol.91, pp.289-305, 2012.

9) J. Nitsche: Über ein variationsprinzip zur Lösung von Dirichlet-Problemen bei verwendung von teilräumen, die keinen randbedingungen unterworfen sind, Abhandlungen aus dem Mathematischen Seminar der Universitat Hamburg, Vol.36, pp.9-15, 1971.

10) D. N. Arnold, F. Brezzi, B. Cockburn, L. D. Marini: Unified analysis of discontinuous galerkin methods for elliptic problems, SIAM J. Numer. Anal., Vol.39, pp.1749-1779, 2002.

11) J. Mergheim, P. Steinmann: A geometrically nonlinear FE approach for the simulation of strong and weak discontinuities, Comput. Methods Appl. Mech. Eng., Vol.195, pp.5037-5052, 2006.

12) P. Wriggers, G. Zavarise: A formulation for frictionless contact problems using a weak form introduced by Nitsche, Comput. Mech., Vol.41, pp.407-420, 2008.

13）山田貴博, 仲田光秀: Nitsche 法に基づくはり要素とソリッ ド要素の接続手法，土木学会論文集 A2, Vol.71, pp.319326, 2015.

14) E. N. Dvorkin, K. J. Bathe: A continuum mechanics based four-node shell element for general non-linear analysis, Eng. Comput., Vol.1, pp.77-88, 1984.

(2017. 6. 23 受付) 


\section{Numerical Procedure for Connecting \\ Shell and Solid Elements Based on Nitsche's Method}

\section{Takeki YAMAMOTO, Takahiro YAMADA, and Kazumi MATSUI}

In the finite element analysis, a structural element is efficient to represent the overall behavior of simulation models. On the other hand, a solid element is used to evaluate local behavior, such as stress concentration for stepped structures. For the purpose of developing a more flexible modeling for the finite element analysis, it is necessary to propose a numerical procedure for connecting shell and solid elements.

In conventional procedures to connect shell and solid elements, a continuity condition for only displacements is imposed at connecting surface. For applying the continuity condition for displacement fields on the interface between shell and solid elements, unreasonable deformation of solid elements near the interface may be observed.

This paper presents a numerical procedure for connecting shell and solid elements by using Nitsche's method, which imposes the continuity conditions for both displacement and stress vectors on the interface. From this approach, shell and solid elements can be connected with reasonable deformation and stress distribution. 